\title{
Genetic polymorphism patterns suggest a genetic driven inflammatory response as pathogenesis in appendicitis
}

\author{
Jan Dimberg $^{1}$ (D) $\cdot$ Marie Rubér $^{2}$ (D) $\cdot$ Marita Skarstedt $^{3}$ (i) $\cdot$ Manne Andersson $^{2,4}$ (D) Roland E. Andersson $^{2,4}$ (i)
}

Accepted: 22 November 2019/Published online: 16 December 2019

(C) The Author(s) 2019

\begin{abstract}
Purpose The pathogenesis of appendicitis is not well understood. Environmental factors are regarded most important, but epidemiologic findings suggest a role of inflammatory and genetic mechanisms. This study determines the association of single nucleotide polymorphisms (SNPs) of inflammatory genes with appendicitis.

Methods As part of a larger prospective study on the diagnostic value of inflammatory variables in appendicitis, the genotype frequency of 28 polymorphisms in 26 inflammatory response genes from the appendicitis and control patients was analyzed in blood samples from 343 patients, 100 with appendicitis, and 243 with non-specific abdominal pain, using TaqMan SNP genotyping assays. Results Associations with appendicitis were found for SNPs IL-13 rs 1800925 with odds ratio (OR) 6.02 (95\% CI 1.52-23.78) for $\mathrm{T} / \mathrm{T}$ versus $\mathrm{C} / \mathrm{C}+\mathrm{T} / \mathrm{T}$, for IL-17 rs2275913 with OR 2.38 (CI 1.24-4.57) for A/A vs G/G + GA, for CCL22 rs 223888 with OR $0.12(0.02-0.90)$, and for A/A vs G/G + GA. Signs of effect modification of age for the association with appendicitis were found for IL-13 rs1800925 and CTLA4 rs3087243. Stratified analysis showed difference in association with severity of disease for IL17 rs2275913 and CD44 rs187115.

Conclusions The association of gene variants on risk of appendicitis and its severity suggest an etiologic role of genetically regulated inflammatory response. This may have implications for understanding the prognosis of untreated appendicitis as a possible self-limiting disorder and for understanding the inverse association of appendicitis with ulcerative colitis.
\end{abstract}

Keywords Appendicitis $\cdot$ Gene polymorphism $\cdot$ Pathophysiology $\cdot$ Inflammatory bowel disease

\section{Introduction}

Appendicitis is the leading cause of abdominal emergency surgery. The etiology of appendicitis is not well known. Obstruction of the outflow from the appendix, usually caused by a fecalith, leading to tissue necrosis and secondary bacterial

Roland E. Andersson

roland.andersson@rjl.se

1 Department of Natural Science and Biomedicine, School of Health and Welfare, Jönköping University, Jönköping, Sweden

2 Department of Clinical and Experimental Medicine, Linköping University, Linköping, Sweden

3 Department of Laboratory Medicine, Division of Clinical Microbiology, Region Jönköping County, Jönköping SE 551 85, Sweden

4 County Hospital Ryhov, Region Jönköping County, Department of Surgery, Jönköping, Sweden invasion, is the leading hypothesis but can only be found in a minority of cases [1]. The occurrence of space-time clustering suggests an infectious etiology but no responsible infectious agent has been identified [2]. A randomized placebocontrolled trial of antibiotics treatment in assumed uncomplicated appendicitis found a high rate of healing with no additional effect of antibiotics, suggesting a non-bacterial etiology in uncomplicated appendicitis [3].

Other possible etiological factors are hormonal effects, supported by differences in incidence rate between the sexes and variations in incidence during the menstrual cycle and pregnancy [4]. Appendicitis is inversely associated with ulcerative colitis (UC) and directly associated with Crohn's disease (CD), suggesting an association for these entities with a common immune response [5-7]. Hereditary factors may also be involved as suggested by differences in the incidence rate associated with the geographic origin in first and secondgeneration immigrants and international adoptees [8].

Two different entities of appendicitis has been suggested, one progressing to gangrene and perforation (advanced) and 
one that resolves spontaneously (phlegmonous) [9]. Advanced and phlegmonous appendicitis may therefore represent the outcome of two different pathogenesis. This hypothesis is also supported by findings of divergent immune regulation in patients with a history of phlegmonous and gangrenous appendicitis $[10,11]$.

Polymorphic variants of genes may mediate and modulate the inflammation in inflammatory bowel diseases [12]. In the present study, we analyze the association of single nucleotide polymorphisms (SNPs) related to inflammatory genes with the risk of appendicitis and its severity.

\section{Methods}

\section{Patients and controls}

The patients in this report comes from a previously reported study which included 432 consecutive patients admitted for suspicion of appendicitis to Linköping University Hospital and County Hospital Ryhov in Jönköping, Sweden, during the period from 1 December 2003 to 17 August 2005 [11]. All patients presenting at the emergency departments with complaints of lower abdominal pain with a duration of less than 5 days were eligible. Pregnant women or patients with any known other inflammatory condition or on antiinflammatory treatment were not included, nor were patients incapable of giving informed consent due to mental illness. Blood samples were taken on admission. The final diagnosis of operated patients was based on a re-examination of the appendix specimen by one pathologist, using a structured protocol and blinded to all clinical information and to the result of the primary histopathologic examination. The histopathologic criterion for phlegmonous appendicitis was an acute, transmural inflammation. Appendices with transmural necrosis or perioperative signs of perforation were characterized as advanced appendicitis. Patients with uninflamed appendices and non-operated patients with unspecified and transient abdominal pain with no established appendicitis diagnosis were deemed to have non-specific abdominal pain (NSAP).

Blood samples for analyzing genomic DNA were available for a subset of 343 of the included patients. All blood samples were centrifuged within $1 \mathrm{~h}$ to separate plasma and blood cells and stored at $-70{ }^{\circ} \mathrm{C}$ until analysis.

The investigated 28 SNPs represent the following genes: interleukin (IL)-1 $\beta$, IL-2, IL-4, IL-4R $\alpha$, IL-5, IL-6, IL-10, IL12B, IL-13, IL-17, and IL-32; chemokines CCL2, CCL11, CCL20, CCL22, and CXCL10; matrix metalloproteinase (MMP)-2, MMP-12, and MMP-13; cluster of differentiation (CD)44; toll-like receptor (TLR)4 and TLR5; interferon (IFN)- $\gamma$; transforming growth factor (TGF)- $\beta$; and cytotoxic T lymphocyte antigen (CTLA)4 (Table 1).
These SNPs were selected because of a known association with inflammatory bowel disease, inflammatory response, recognizing bacterial molecules and intestinal injury. Most of them are promoter SNPs with an effect on the transcription level of the cytokines.

\section{DNA preparation and genotyping}

Genomic DNA was isolated from blood samples using QiaAmp DNA Kit (Qiagen, Hilden, Germany). DNA samples were genotyped using the TaqMan SNP assays (Applied Biosystems, Foster City, CA, USA) of the 28 SNPs according to Table 1. DNA (10 ng) was mixed with Taqman Genotyping Master Mix (Applied Biosystems) and was amplified using the CFX96 Real-Time system (Bio-Rad). Amplification was performed using an initial cycle at $50{ }^{\circ} \mathrm{C}$ for $2 \mathrm{~min}$, followed by one cycle at $95^{\circ} \mathrm{C}$ for $10 \mathrm{~min}$, and finally 40 cycles at $95^{\circ} \mathrm{C}$ for $15 \mathrm{~s}$ and at $60^{\circ} \mathrm{C}$ for $1 \mathrm{~min}$. The Bio-Rad CFX Manager software, version 3.1 (Bio-Rad, CA, USA) was used to assign the genotypes.

\begin{tabular}{llll}
$\begin{array}{l}\text { Table 1 The single } \\
\text { nucleotide } \\
\text { polymorphism (SNP) } \\
\text { genes included in the }\end{array}$ & Gene & SNP rs number & Reference \\
study & IL-1 $\beta$ & rs16944 & {$[13]$} \\
& IL-2 & rs2069762 & {$[13]$} \\
IL-2 & rs6822844 & {$[12]$} \\
IL-4 & rs2243250 & {$[14]$} \\
IL-4R $\alpha$ & rs1801275 & {$[14]$} \\
IL-5 & rs2069812 & {$[13]$} \\
IL-6 & rs1800797 & {$[13]$} \\
IL-6 & rs1800795 & {$[15]$} \\
IL-10 & rs1800896 & {$[13]$} \\
IL-12B & rs3212227 & {$[16]$} \\
IL-13 & rs1800925 & {$[14]$} \\
IL-17 & rs2275913 & {$[12]$} \\
IL-32 & rs4786370 & {$[17]$} \\
CCL2 & rs1024611 & {$[18]$} \\
CCL20 & rs6749704 & {$[19]$} \\
CCL22 & rs223888 & {$[20]$} \\
CCL11 & rs17809012 & {$[21]$} \\
MMP-2 & rs243865 & {$[22]$} \\
MMP-9 & rs2274755 & {$[23]$} \\
MMP-12 & rs2276109 & {$[24]$} \\
MMP-13 & rs2252070 & {$[24]$} \\
CD44 & rs187115 & {$[25]$} \\
TLR4 & rs4986790 & {$[26]$} \\
TLR5 & rs5744174 & {$[27]$} \\
IFN- $\gamma$ & rs2069705 & {$[13]$} \\
TGF- $\beta$ & rs1800469 & {$[13]$} \\
CXCL10 & rs8878 & {$[28]$} \\
CTLA4 & rs3087243 & {$[29]$} \\
\hline & & & \\
& & & \\
& & & \\
& & & \\
& & & \\
& & & \\
& &
\end{tabular}




\section{Ethics}

All patients were given written and verbal information. Verbal consent, obtained from the patient or from the legal guardian for children, was accepted. The study was approved by The Regional Ethical Review Board at Linköping number FEK 03-225 and M148-04.

\section{Statistical analysis}

Distribution of genotypes in the appendicitis and NSAP patients and in subgroups of appendicitis patients according to clinical characteristics, severity of disease, and age (stratified at the median age 22 years) was analyzed using chi-squared or Fishers exact test, where appropriate. Differences between the groups were expressed as odds ratio (OR) with $95 \%$ confidence intervals (CI). The presence of effect modification on the multiplicative and additive scale was assessed from the ratio of odds ratios and estimates of the attributable proportion, respectively. The Hardy-Weinberg equilibrium was tested for the genotypes. Statistical analysis was performed using Stata Statistical Software Release 15, Stata Corp. College Station, TX, USA and SPSS software for Windows, version 14.0 (SPSS, Inc., Chicago, IL, USA). Results were considered significant at $p<0.05$.

\section{Results}

We included 100 patients (57 males and 43 females) with a final diagnosis of appendicitis and 243 patients (106 males and 137 females) with a final diagnosis of non-specific abdominal pain (NSAP).

\section{Genotype distributions of selected SNPs in the appendicitis patients and controls}

Significant differences in the genotype distribution were observed between the appendicitis and NSAP patients for IL-13, IL-17 and CCL22 (Table 2). In patients with appendicitis, $7.0 \%$ had genotypes IL-13 T/T and 93\% had IL-13 C/C + $\mathrm{C} / \mathrm{T}$. The corresponding proportions for the NSAP patients were $1.2 \%$ and $98.8 \%(p=0.008)$, respectively. The frequency of IL-17 A/A and IL-17 G/G + G/A was $20.0 \%$ and $80 \%$ in the appendicitis patients compared with $9.5 \%$ and $90.5 \%$ in the NSAP patients $(p=0.025)$, respectively. The IL-13 T/T and IL-17 A/A genotypes were associated with an increased risk of appendicitis with $\mathrm{OR}=6.02$ and $\mathrm{OR}=2.38$, respectively (Table 2).

For the CCL22 genotypes, we found a marked rare presence of the genotype $\mathrm{A} / \mathrm{A}$ in appendicitis (1.0\%) compared with the NSAP patients $(7.8 \%)(p=0.011)$ (Table 2). The CCL22 genotype A/A was thus associated with a low risk of appendicitis with an $\mathrm{OR}=0.12$. All other polymorphisms investigated showed a lack of statistically significant association with appendicitis (data not shown). Each polymorphism was in Hardy-Weinberg equilibrium.

\section{Genotype distributions in stratified analyses}

Stratified analysis showed a difference between younger and older appendicitis patients in the distribution of genotypes for CTLA4 and IL-13 with signs of effect modification of age for the association with appendicitis (Tables 3 and 4).

The genotype CTLA4 G/A + A/A was associated with a higher risk of appendicitis in younger patients and a lower risk in older patients with significant indices for both multiplicative and additive effect modification. Genotypes IL-13 C/T + $\mathrm{T} / \mathrm{T}$ was associated with a higher risk of appendicitis in the younger patients and a lower risk in older patients, with a nonsignificant ORs within the strata, but significant ratio of ORs (ROR $0.32, p=0.023$ ), suggesting an additive effect modification.

An association with severity of disease was found for IL-17 and CD44 with an increased risk for advanced appendicitis associated with the genotype IL-17 A/A (OR 3.17) and CD44 $\mathrm{G} / \mathrm{G}+\mathrm{G} / \mathrm{A}(\mathrm{OR} 3.8$ ) compared with $\mathrm{IL}-17 \mathrm{G} / \mathrm{A}+\mathrm{G} / \mathrm{G}$ and CD44 A/A, respectively (Table 5). For IL-6, we found a lower frequency of the A/A genotype in advanced appendicitis (8.3\%) compared to patients with simple appendicitis or NSAP $(18.8 \%)$. However, this association was nonsignificant $(p=0.28)$ probably due to the small sample size.

\section{Discussion}

We report for the first time an association of appendicitis with polymorphism in five genes (IL-13, IL-17, CCL22, CTLA4, and CD44). We found a non-significant association with advanced appendicitis for SNP IL-6 rs1800975 which can give support to a previously reported association in a larger sample and confirmed previous reports of no association of SNP TLR4 rs4986790 with appendicitis [15, 30].

Understanding the pathogenesis of appendicitis may have important implications for the choice of treatment. Untreated appendicitis has been regarded as a progressive condition that eventually will lead to tissue necrosis and perforation, emphasizing the need of early surgical treatment [1]. This is certainly the case when luminal obstruction is present, which is however only found in a minority of cases. Antibiotics treatment has recently been proposed as an efficient alternative to surgery in uncomplicated appendicitis [31]. However, a placebocontrolled study of antibiotics treatment found a high rate of healing in the placebo arm and no additional effect of antibiotics [3]. This is in line with the hypothesis of two different 
Table 2 Association of genotypes with appendicitis. Distribution of SNP genotypes in percent $(n)$ in acute appendicitis patients (AA) and controls with non-specific abdominal pain (NSAP), and association expressed as odds ratio (OR) with $95 \%$ confidence interval $(\mathrm{CI})$

\begin{tabular}{llccccc}
\hline Gene/SNP & Genotype & AA $^{\mathrm{a}}$ & NSAP $^{\mathrm{b}}$ & $P$ value & OR (95\% CI) & $P$ value \\
\hline IL-13/rs1800925 & $\mathrm{C} / \mathrm{C}$ & $66.0(66)$ & $63.4(154)$ & & & \\
& $\mathrm{C} / \mathrm{T}$ & $27.0(27)$ & $35.4(86)$ & & & \\
& $\mathrm{T} / \mathrm{T}$ & $7.0(7)$ & $1.2(3)$ & $0.009^{\mathrm{c}}$ & $6.02(1.52-23.78)$ & 0.01 \\
& $\mathrm{C} / \mathrm{C}+\mathrm{C} / \mathrm{T}$ & $93.0(93)$ & $98.8(240)$ & 0.008 & 1 & \\
IL-17/rs2275913 & $\mathrm{G} / \mathrm{G}$ & $40.0(40)$ & $42.2(102)$ & & & \\
& $\mathrm{G} / \mathrm{A}$ & $20.0(20)$ & $48.3(117)$ & & & \\
& $\mathrm{A} / \mathrm{A}$ & $80.0(80)$ & $9.5(23)$ & $0.044^{\mathrm{c}}$ & $2.38(1.24-4.57)$ & \\
& $\mathrm{G} / \mathrm{G}+\mathrm{G} / \mathrm{A}$ & & $90.5(219)$ & 0.011 & 1 & \\
$\mathrm{CCL} 22 / \mathrm{rs} 223888$ & $\mathrm{G} / \mathrm{G}$ & $55.0(55)$ & $55.6(135)$ & & & 0.039 \\
& $\mathrm{G} / \mathrm{A}$ & $44.0(44)$ & $36.6(89)$ & & & \\
& $\mathrm{A} / \mathrm{A}$ & $1.0(1)$ & $7.8(19)$ & $0.024^{\mathrm{c}}$ & $0.12(0.02-0.90)$ & \\
& $\mathrm{G} / \mathrm{G}+\mathrm{G} / \mathrm{A}$ & $99.0(99)$ & $92.2(224)$ & 0.011 & 1 & \\
\hline
\end{tabular}

${ }^{\mathrm{a}} n=100$ total subjects

${ }^{\mathrm{b}} n=243$, except IL-17 $n=242$ total subjects

${ }^{\mathrm{c}}$ AA vs. NSAP, overall total subjects entities of appendicitis, one progressing to perforation and another that will resolve spontaneously if untreated [32].

An immunologically driven pathogenesis in appendicitis has been suggested based on inverse relation between appendicitis and UC in patients younger than age 20 years, a positive association with $\mathrm{CD}$ and a low incidence during third trimester pregnancy followed by a rebound effect with a peak in incidence post-partum [4-7].

The immune response can induce or exaggerate diseases through the local production of cytokines, which may be reflected by increased levels in plasma, serum, and peripheral blood mononuclear cells in appendicitis patients $[10,11]$. The cytokine production can at least partially be influenced by genetic polymorphisms in cytokine genes, which can play a role in susceptibility to various diseases $[12,13,15]$. The associations found in the present study may therefore suggest a pathogenetic role of IL-13 rs1800925, IL-17A rs2275913 and CCL22 rs223888 with an increased risk for appendicitis associated with genotypes IL-13 T/T, IL-17 A/A, and a low risk for carriers of the genotype CCL22 A/A.

An observed inverse association between appendectomy and ulcerative colitis has been proposed to be an immunological effect of the appendectomy itself. Epidemiological studies have however shown clear evidence that the association is related to appendicitis in young age [5,6]. A hypothetical mechanism could be that one or several constitutional genetic factor(s) have inverse associations with appendicitis in young age and ulcerative colitis. Interestingly, we found signs of an effect modification of age for the CTLA4 gene, with a lower proportion of CTLA4 genotype $\mathrm{G} / \mathrm{G}$ in appendicitis patients $\leq$
Table 3 Effect of age on the association of genes with appendicitis. Distribution of SNP genotypes in percent $(n)$ in acute appendicitis patients (AA) and controls with non-specific abdominal pain (NSAP), stratified by age

\begin{tabular}{|c|c|c|c|c|c|c|c|}
\hline \multirow[b]{2}{*}{ Gene/SNP } & & \multicolumn{3}{|c|}{ Age $\leq 22$ years } & \multicolumn{3}{|c|}{ Age $>22$ years } \\
\hline & & AA & NSAP & $P$ value & $\mathrm{AA}$ & NSAP & $P$ value \\
\hline \multicolumn{8}{|c|}{ IL-13/rs1800925 } \\
\hline & $\mathrm{C} / \mathrm{C}$ & $58.0(29)$ & $68.3(84)$ & & $74.0(37)$ & $58.3(70)$ & \\
\hline & $\mathrm{C} / \mathrm{T}$ & $38.0(19)$ & $31.7(39)$ & & $16.0(8)$ & $39.2(47)$ & \\
\hline & $\mathrm{T} / \mathrm{T}$ & $4.0(2)$ & $0.0(0)$ & $0.054^{\mathrm{a}}$ & $10.0(5)$ & $2.5(3)$ & $0.003^{\mathrm{a}}$ \\
\hline & $\mathrm{C} / \mathrm{T}+\mathrm{T} / \mathrm{T}$ & $43.0(21)$ & $31.7(39)$ & $0.220^{\mathrm{b}}$ & $26.0(13)$ & $41.7(50)$ & $0.058^{\mathrm{b}}$ \\
\hline \multicolumn{8}{|c|}{ CTLA4/rs3087243 } \\
\hline & $\mathrm{G} / \mathrm{G}$ & $28.0(14)$ & $42.3(52)$ & & $58.0(29)$ & $37.5(45)$ & \\
\hline & $\mathrm{G} / \mathrm{A}$ & $54.0(27)$ & $41.5(51)$ & & $32.0(16)$ & $48.3(58)$ & \\
\hline & $\mathrm{A} / \mathrm{A}$ & $18.0(9)$ & $16.3(20)$ & $0.197^{\mathrm{a}}$ & $10.0(5)$ & $14.2(17)$ & $0.048^{\mathrm{a}}$ \\
\hline & $\mathrm{G} / \mathrm{A}+\mathrm{A} / \mathrm{A}$ & $72.0(36)$ & $57.7(71)$ & $0.087^{\mathrm{c}}$ & $42.0(21)$ & $62.5(75)$ & $0.018^{\mathrm{c}}$ \\
\hline
\end{tabular}

${ }^{\mathrm{a}} \mathrm{AA}$ vs. NSAP, overall

${ }^{\mathrm{b}} \mathrm{C} / \mathrm{T}+\mathrm{T} / \mathrm{T}$ vs $\mathrm{C} / \mathrm{C}$

${ }^{\mathrm{c}} \mathrm{G} / \mathrm{A}+\mathrm{A} / \mathrm{A}$ vs $\mathrm{G} / \mathrm{G}$ 
Table 4 Analysis of effect modification of age on the association of genotype with appendicitis. The ratio of ORs suggests a multiplicative effect modification for both genes. The attributable proportion suggest an additive effect modification for CTLA4

\begin{tabular}{|c|c|c|c|c|c|}
\hline Genotype & $\begin{array}{l}\text { Numbers AA/ } \\
\text { NSAP and }(\% \\
\text { AA) }\end{array}$ & $\begin{array}{l}\text { Risk for appendicitis } \\
\text { according to genotype within } \\
\text { strata of age OR }(95 \% \mathrm{CI}), p \\
\text { value }\end{array}$ & $\begin{array}{l}\text { Numbers AA/ } \\
\text { NSAP and (\% } \\
\text { AA) }\end{array}$ & $\begin{array}{l}\text { Risk for appendicitis } \\
\text { according to genotype within } \\
\text { strata of age OR }(95 \% \mathrm{CI}), p \\
\text { value }\end{array}$ & $\begin{array}{l}\text { Risk for appendicitis in older } \\
\text { vs younger patients within } \\
\text { strata of genotype OR }(95 \% \mathrm{CI} \text {, } \\
p \text { value }\end{array}$ \\
\hline IL-13 & Age $\leq 22$ years. & & Age $>22$ years & & \\
\hline $\mathrm{C} / \mathrm{C}$ & $29 / 84(25.7)$ & 1 & $37 / 70(34.6)$ & 1 & $1.53(0.86-2.74), p=0.150$ \\
\hline $\mathrm{C} / \mathrm{T}+\mathrm{T} / \mathrm{T}$ & $21 / 39(35.0)$ & $1.56(0.79-3.07), p=0.199$ & $13 / 50(20.6)$ & $0.49(0.24-1.02), p=0.056$ & $0.48(0.22-1.08), p=0.078$ \\
\hline $\begin{array}{l}\text { Ratio of } \\
\text { ORs } \\
\text { CTLA4 }\end{array}$ & \multicolumn{5}{|c|}{$0.32(95 \%$ CI $0.12-0.85), p=0.023$} \\
\hline $\mathrm{G} / \mathrm{G}$ & $14 / 52(21.2)$ & 1 & $29 / 45(39.2)$ & 1 & $2.45(1.14-5.27), p=0.021$ \\
\hline $\mathrm{A} / \mathrm{A}+\mathrm{A} / \mathrm{G}$ & $36 / 71(33.6$ & $1.88(0.92-3.84), p=0.082$ & $21 / 75(21.9)$ & $0.43(0.22-0.85), p=0.015$ & $0.61(0.33-1.13), p=0.114$ \\
\hline $\begin{array}{c}\text { Ratio of } \\
\text { ORs }\end{array}$ & $\begin{array}{c}0.23(95 \% \mathrm{CI} \\
0.09-0.61) \\
p=0.003\end{array}$ & & & & \\
\hline $\begin{array}{l}\text { Attributable } \\
\text { proportion }\end{array}$ & $\begin{array}{c}-2.15, \mathrm{CI}-4.23 \\
\text { to }-0.07 \\
p=0.043\end{array}$ & & & & \\
\hline
\end{tabular}

22 years, whereas genotype $\mathrm{G} / \mathrm{A}+\mathrm{A} / \mathrm{A}$ was less common in appendicitis patients $>22$ years.

CTLA4 is expressed on T cells and is involved in tolerance and downregulation of T cell activation [29]. Previous studies found an increased risk of UC associated with SNP CTLA4 rs3087243 G>A and a dominance of the genotype A/A and lower extent of the genotype $\mathrm{G} / \mathrm{G}$ in healthy control subjects compared to patients with ulcerative colitis $[29,33]$. This SNP also seems to have an effect on the expression of the CTLA4 gene [29]. The effect modification of age for the CTLA4 gene on the risk of appendicitis could explain the inverse association seen between appendectomy for appendicitis at young age and the development of ulcerative colitis.

An association to the pregnancy related variations in the Th1/Th2 balance has been proposed as an explanation to the strong variations in incidence during pregnancy $[9,10]$. The Th2-dominated profile during the third trimester should accordingly be protecting against appendicitis. IL-13 is produced by T helper 2 (Th2) cells [12]. The SNP IL-13 rs1800925 affects the IL-13 production to a higher level by
Table 5 Association of genotypes with severity of disease. Distribution of SNP genotypes in percent $(n)$ in patients with non-specific abdominal pain, advanced, and phlegmonous appendicitis

\begin{tabular}{llllll}
\hline Genotype & NSAP & AdvA & $P$ value $^{\mathrm{a}}$ & PA & $P$ value $^{\mathrm{b}}$ \\
\hline IL-17/rs2275913 & & & & & \\
G/G & $42.2(102)$ & $20.8(5)$ & & $46.1(35)$ & \\
G/A & $48.4(117)$ & $54.2(13)$ & & $35.5(27)$ & \\
A/A & $9.5(23)$ & $25.0(6)$ & 0.025 & $18.4(14)$ & 0.048 \\
G/G + G/A & $90.5(219)$ & $75.0(18)$ & 0.033 & $81.6(62)$ & 0.041 \\
A/A vs G/G + G/A & Ref & OR 3.17 (1.15-8.79) & 0.026 & OR 2.15 (1.04-4.42) & 0.038 \\
CD44/rs187115 & & & & & \\
A/A & $43.2(105)$ & $16.7(4)$ & & $58.0(37)$ & \\
G/A & $47.7(116)$ & $70.8(17)$ & & $32.0(27)$ & 0.089 \\
G/G & $9.1(22)$ & $12.5(3)$ & 0.025 & $10.0(12)$ & 0.429 \\
G/G + G/A & $56.8(138)$ & $83.3(20)$ & 0.015 & $42.0(39)$ & 0.402 \\
G/G + G/A vs A/A & Ref & OR 3.80(1.26-11.46) & 0.018 & OR 0.80 (0.48-1.34) \\
\hline
\end{tabular}

NSAP non-specific abdominal pain, $n=242 ; A d v A$ advanced appendicitis, $n=24, P A$ phlegmonous appendicitis, $n=76$

$\mathrm{OR}$ is association expressed as Odds Ratio

${ }^{a}$ NSAP vs AdvA

${ }^{\mathrm{b}}$ NSAP vs PA 
the $\mathrm{T}$ allele, and the genotype $\mathrm{C} / \mathrm{T}$ and allele $\mathrm{T}$ is associated with a higher risk of $\mathrm{CD}$ and $\mathrm{UC}[34,35]$. IL-13 producing NK T-cells is also associated with a Th2-like inflammation in ulcerative colitis [36].

IL-13 plays a positive role in the induction and maintenance of $\mathrm{IgE}$ production and $\operatorname{IgE}$ mediated allergic responses [37]. Recently, it has been shown that children with IgE mediated allergy had a lower risk of complicated appendicitis [38].

We found an increased risk of appendicitis associated with IL-17A rs2275913 allele A. IL-17 is secreted by T helper 17 (Th17) cells and acts on a variety of cells which respond by upregulating expression of inflammatory cytokines, chemokines, and metalloproteases [12]. The expression of IL-17 is increased in intestinal mucosa of patients with inflammatory bowel disease [39]. Ruber et al. noted higher level of IL-17 and a pattern of inflammatory markers consistent with inflammatory Th1 in sera from patients with advanced appendicitis compared to phlegmonous appendicitis [11]. The minor allele A is more common in UC patients than in controls [12]. The IL-17A rs2275913 SNP is a functional polymorphism that modifies the binding of the nuclear factor activated $T$ cells (NFAT) to the IL-17A promoter [40]. The A allele allows a stronger binding of NFAT, leading to a higher transcription and synthesis of the IL-17A. This data may partially support the described linkage of IL-17 to intestinal inflammation including phenotypic differences in appendicitis $[11,12,39]$.

We found that carriers of the G allele in CCL22 rs223888 $(\mathrm{G}>\mathrm{A})$ influence susceptibility to appendicitis and thereby constitute risk factor. Chemokines play an important role in the migration of immune cells to sites of inflammation and injury including the intestinal mucosa. The chemokine CCL22 is expressed in macrophages, dendritic cells, B cells, and intestinal epithelial cells and is a ligand for $\mathrm{CC}$ chemokine receptor 4 (CCR4). Consequently, CCL22 attracts CCR4bearing cells such as $\mathrm{Th} 2 \mathrm{CD}^{+}$and regulatory $\mathrm{T}$ cells (Treg) which may direct Th2-like inflammation and the immune balance in the intestinal mucosa [41, 42].

We found a stronger association of advanced appendicitis with the genotypes $A / G+G / G$ of SNP CD44 rs187115 compared to phlegmonous appendicitis suggesting that carriers of allele $G$ have an increased risk of the development of advanced appendicitis. CD44 is an adhesion molecule expressed on different cell types with a wide variety of cellular functions including lymphocyte homing, inflammation, cell migration, and apoptosis [43]. Specifically, CD44 mediates interactions between the intestinal endothelium and circulating Th1 and Th2 lymphocytes, including rolling and adhesion [44]. Moreover, increased expression of CD44 has been detected in epithelium of UC and CD compared with controls [45].

The role of CD44 genetic polymorphism for the severity of local systemic inflammation has not been well studied, and it has not been clarified how this polymorphism influences the activity and expression of CD44. As CD44 has been linked to lymphocyte homing and inflammation [43], one may speculate that polymorphism in the CD44 gene might influence the aggressiveness of the inflammatory response.

Very few studies have reported about the association of genetic polymorphisms with appendicitis $[15,30,46]$. The present study provides novel information on the effects of the gene variant of IL-13, IL-17, CCL22, CTLA4, and CD44 on risk of appendicitis and severity of disease. The present study has relative low number of participants and was conducted in two hospitals in Sweden. The participants may therefore not be representative of the Swedish population. Secondly, it cannot be excluded that the investigated polymorphisms may be in linkage disequilibrium with other polymorphisms which modulate the susceptibility to appendicitis. Finally, the reference group consisted of patients with the non-specific diagnosis of NSAP. We cannot exclude that some of the non-operated patients with a NSAP diagnosis had in fact resolving appendicitis. This may however most likely lead to weakened associations.

In conclusion, we found polymorphisms in five genes that were associated with appendicitis and its severity. For two of these genes, we found age-related differences that are consistent with age related differences in the association of appendicitis and ulcerative colitis. These findings suggest that appendicitis is associated with a genetically orchestrated inflammatory response. This gives a new perspective on the etiology and pathogenesis of appendicitis and opens for an understanding of the links with chronic inflammatory bowel diseases. Identifying appendicitis as an inflammatory condition, as opposed to a bacterial infection, may also have a bearing on the current controversy regarding the efficiency of antibiotics treatment of uncomplicated appendicitis.

Funding information Open access funding provided by Linköping University. The study was supported by Medical Research Council of Southeast Sweden grants nr FORSS-3974, FORSS-36021, and Futurum-Academy for Health and Care, Jönköping County Council, Sweden.

\section{Compliance with ethical standards}

All patients were given written and verbal information. Verbal consent, obtained from the patient or from the legal guardian for children, was accepted. The study was approved by The Regional Ethical Review Board at Linköping number FEK 03-225 and M148-04.

Conflict of interest The authors declare that they have no conflict of interest.

Open Access This article is licensed under a Creative Commons Attribution 4.0 International License, which permits use, sharing, adaptation, distribution and reproduction in any medium or format, as long as you give appropriate credit to the original author(s) and the source, provide a link to the Creative Commons licence, and indicate if changes were made. The images or other third party material in this article are included in the article's Creative Commons licence, unless indicated otherwise in a 
credit line to the material. If material is not included in the article's Creative Commons licence and your intended use is not permitted by statutory regulation or exceeds the permitted use, you will need to obtain permission directly from the copyright holder. To view a copy of this licence, visit http://creativecommons.org/licenses/by/4.0/.

\section{References}

1. Humes DJ, Simpson J (2006) Acute appendicitis. Bmj 333(7567): 530-534. https://doi.org/10.1136/bmj.38940.664363.AE

2. Andersson R, Hugander A, Thulin A, Nystrom PO, Olaison G (1995) Clusters of acute appendicitis: further evidence for an infectious aetiology. Int J Epidemiol 24(4):829-833. https://doi.org/10. 1093/ije/24.4.829

3. Park HC, Kim MJ, Lee BH (2017) Randomized clinical trial of antibiotic therapy for uncomplicated appendicitis. Br J Surg 104(13):1785-1790. https://doi.org/10.1002/bjs.10660

4. Andersson RE, Lambe M (2001) Incidence of appendicitis during pregnancy. Int J Epidemiol 30(6):1281-1285. https://doi.org/10. 1093/ije/30.6.1281

5. Andersson RE, Olaison G, Tysk C, Ekbom A (2001) Appendectomy and protection against ulcerative colitis. N Engl J Med 344(11):808-814. https://doi.org/10.1056/ nejm200103153441104

6. Frisch M, Pedersen BV, Andersson RE (2009) Appendicitis, mesenteric lymphadenitis, and subsequent risk of ulcerative colitis: cohort studies in Sweden and Denmark. Bmj 338:b716. https://doi. org/10.1136/bmj.b716

7. Andersson RE, Olaison G, Tysk C, Ekbom A (2003) Appendectomy is followed by increased risk of Crohn's disease. Gastroenterology 124(1):40-46. https://doi.org/10.1053/gast.2003. 50021

8. Terlinder J, Andersson RE (2016) Incidence of appendicitis according to region of origin in first- and second-generation immigrants and adoptees in Sweden. A cohort follow-up study. Scand J Gastroenterol 51(1):111-120. https://doi.org/10.3109/00365521. 2015.1030688

9. Andersson R, Hugander A, Thulin A, Nystrom PO, Olaison G (1994) Indications for operation in suspected appendicitis and incidence of perforation. Bmj 308(6921):107-110. https://doi.org/10. 1136/bmj.308.6921.107

10. Ruber M, Berg A, Ekerfelt C, Olaison G, Andersson RE (2006) Different cytokine profiles in patients with a history of gangrenous or phlegmonous appendicitis. Clin Exp Immunol 143(1):117-124. https://doi.org/10.1111/j.1365-2249.2005.02957.x

11. Ruber M, Andersson M, Petersson BF, Olaison G, Andersson RE, Ekerfelt C (2010) Systemic Th17-like cytokine pattern in gangrenous appendicitis but not in phlegmonous appendicitis. Surgery 147(3):366-372. https://doi.org/10.1016/j.surg.2009.09.039

12. Magyari L, Kovesdi E, Sarlos P, Javorhazy A, Sumegi K, Melegh B (2014) Interleukin and interleukin receptor gene polymorphisms in inflammatory bowel diseases susceptibility. World J Gastroenterol 20(12):3208-3222. https://doi.org/10.3748/wjg.v20.i12.3208

13. Erdei E, Kang H, Meisner A, White K, Pickett G, Baca C, Royce M, Berwick M (2010) Polymorphisms in cytokine genes and serum cytokine levels among New Mexican women with and without breast cancer. Cytokine 51(1):18-24. https://doi.org/10.1016/j. cyto.2010.03.014

14. Shamoun L, Skarstedt M, Andersson RE, Wagsater D, Dimberg J (2018) Association study on IL-4, IL-4Ralpha and IL-13 genetic polymorphisms in Swedish patients with colorectal cancer. Clin
Chim Acta 487:101-106. https://doi.org/10.1016/j.cca.2018.09. 024

15. Daneshmandi S, Ghasemi A, Pourfathollah AA (2009) IL-6 -174G/ C promoter polymorphism in acute appendicitis. Lab Med 40:600 6003

16. Li J, Zhang C, Wang JB, Chen SS, Zhang TP, Li S, Pan HF, Ye DQ (2016) Relationship between the IL12B (rs3212227) gene polymorphism and susceptibility to multiple autoimmune diseases: a metaanalysis. Mod Rheumatol 26(5):749-756. https://doi.org/10.3109/ 14397595.2016.1157282

17. Shamoun L, Kolodziej B, Andersson RE, Dimberg J (2018) Protein expression and genetic variation of IL32 and association with colorectal cancer in Swedish patients. Anticancer Res 38(1):321-328. https://doi.org/10.21873/anticanres.12225

18. Pham MH, Bonello GB, Castiblanco J, Le T, Sigala J, He W, Mummidi S (2012) The rs 1024611 regulatory region polymorphism is associated with CCL2 allelic expression imbalance. PLoS One 7(11):e49498. https://doi.org/10.1371/journal.pone. 0049498

19. Jafarzadeh A, Bagherzadeh S, Ebrahimi HA, Hajghani H, Bazrafshani MR, Khosravimashizi A, Nemati M, Gadari F, Sabahi A, Iranmanesh F, Mohammadi MM, Daneshvar H (2014) Higher circulating levels of chemokine CCL20 in patients with multiple sclerosis: evaluation of the influences of chemokine gene polymorphism, gender, treatment and disease pattern. J Mol Neurosci 53(3):500-505. https://doi.org/10.1007/s12031-0130214-2

20. Wagsater D, Dienus O, Lofgren S, Hugander A, Dimberg J (2008) Quantification of the chemokines CCL17 and CCL22 in human colorectal adenocarcinomas. Mol Med Rep 1(2):211-217

21. Chang HS, Kim JS, Lee JH, Cho JI, Rhim TY, Uh ST, Park BL, Chung IY, Park CS, Shin HD (2005) A single nucleotide polymorphism on the promoter of eotaxin1 associates with its mRNA expression and asthma phenotypes. J Immunol 174(3):1525-1531. https://doi.org/10.4049/jimmunol.174.3.1525

22. Shajarehpoor Salavati L, Tafvizi F, Manjili HK (2017) The association between MMP2 -1306 C > T (rs243865) polymorphism and risk of prostate cancer. Ir J Med Sci 186(1):103-111. https://doi.org/ 10.1007/s11845-016-1492-9

23. Jimenez-Morales S, Martinez-Aguilar N, Gamboa-Becerra R, Jimenez-Ruiz JL, Lopez-Ley D, Lou H, Saldana-Alvarez Y, Dean M, Orozco L (2013) Polymorphisms in metalloproteinase-9 are associated with the risk for asthma in Mexican pediatric patients. Hum Immunol 74(8):998-1002. https://doi.org/10.1016/j. humimm.2013.04.036

24. Van Nguyen S, Skarstedt M, Löfgren S, Zar N, Andersson RE, Lindh M, Matussek A, Dimberg J (2013) Gene polymorphism of matrix metalloproteinase-12 and -13 and association with colorectal cancer in Swedish patients. Anticancer Res 33(8):3247-3250

25. Zhang M, Wang Y, Fang T, Cai Y, Xu Y, Yan C, Zhang L, Liang C (2016) Common polymorphisms in CD44 gene and susceptibility to cancer: a systematic review and meta-analysis of 45 studies. Oncotarget 7(46):76021-76035. https://doi.org/10.18632/ oncotarget. 12580

26. Landi S, Gemignani F, Bottari F, Gioia-Patricola L, Guino E, Cambray M, Biondo S, Capella G, Boldrini L, Canzian F, Moreno V (2006) Polymorphisms within inflammatory genes and colorectal cancer. J Negat Results Biomed 5:15-15. https://doi.org/ 10.1186/1477-5751-5-15

27. Zeng HM, Pan KF, Zhang Y, Zhang L, Ma JL, Zhou T, Su HJ, Li WQ, Li JY, Gerhard M, Classen M, You WC (2011) Genetic variants of toll-like receptor 2 and 5, helicobacter pylori infection, and risk of gastric cancer and its precursors in a Chinese population. Cancer Epidemiol Biomark Prev 20(12):2594-2602. https://doi. org/10.1158/1055-9965.Epi-11-0702 
28. Dimberg J, Skarstedt M, Lofgren S, Zar N, Matussek A (2014) Protein expression and gene polymorphism of CXCL10 in patients with colorectal cancer. Biomed Rep 2(3):340-343. https://doi.org/ 10.3892/br.2014.255

29. Repnik K, Potocnik U (2010) CTLA4 CT60 single-nucleotide polymorphism is associated with Slovenian inflammatory bowel disease patients and regulates expression of CTLA4 isoforms. DNA Cell Biol 29(10):603-610. https://doi.org/10.1089/dna. 2010.1021

30. Rivera-Chavez FA, Peters-Hybki DL, Barber RC, Lindberg GM, Jialal I, Munford RS, O'Keefe GE (2004) Innate immunity genes influence the severity of acute appendicitis. Ann Surg 240(2):269277. https://doi.org/10.1097/01.sla.0000133184.10676.26

31. Sallinen V, Akl EA, You JJ, Agarwal A, Shoucair S, Vandvik PO, Agoritsas T, Heels-Ansdell D, Guyatt GH, Tikkinen KA (2016) Meta-analysis of antibiotics versus appendicectomy for nonperforated acute appendicitis. Br J Surg 103(6):656-667. https:// doi.org/10.1002/bjs.10147

32. Andersson RE (2007) The natural history and traditional management of appendicitis revisited: spontaneous resolution and predominance of prehospital perforations imply that a correct diagnosis is more important than an early diagnosis. World J Surg 31(1):86-92. https://doi.org/10.1007/s00268-006-0056-y

33. Zhao JJ, Wang D, Yao H, Sun DW, Li HY (2015) CTLA-4 and MDR1 polymorphisms increase the risk for ulcerative colitis: a meta-analysis. World J Gastroenterol 21(34):10025-10040. https://doi.org/10.3748/wjg.v21.i34.10025

34. van der Pouw Kraan TC, van Veen A, Boeije LC, van Tuyl SA, de Groot ER, Stapel SO, Bakker A, Verweij CL, Aarden LA, van der Zee JS (1999) An IL-13 promoter polymorphism associated with increased risk of allergic asthma. Genes Immun 1(1):61-65. https:// doi.org/10.1038/sj.gene.6363630

35. Walczak A, Przybylowska K, Dziki L, Sygut A, Chojnacki C, Chojnacki J, Dziki A, Majsterek I (2012) The IL-8 and IL-13 gene polymorphisms in inflammatory bowel disease and colorectal cancer. DNA Cell Biol 31(8):1431-1438. https://doi.org/10.1089/dna. 2012.1692

36. Fuss IJ, Heller F, Boirivant M, Leon F, Yoshida M, Fichtner-Feigl S, Yang Z, Exley M, Kitani A, Blumberg RS, Mannon P, Strober W (2004) Nonclassical CD1d-restricted NK T cells that produce IL-13 characterize an atypical Th2 response in ulcerative colitis. J Clin Invest 113(10):1490-1497. https://doi.org/10.1172/jci19836
37. de Vries JE (1998) The role of IL-13 and its receptor in allergy and inflammatory responses. J Allergy Clin Immunol 102(2):165-169. https://doi.org/10.1016/s0091-6749(98)70080-6

38. Salo M, Gudjonsdottir J, Omling E, Hagander L, Stenstrom P (2018) Association of IgE-mediated allergy with risk of complicated appendicitis in a pediatric population. JAMA Pediatr 172(10): 943-948. https://doi.org/10.1001/jamapediatrics.2018.1634

39. Fujino S, Andoh A, Bamba S, Ogawa A, Hata K, Araki Y, Bamba T, Fujiyama Y (2003) Increased expression of interleukin 17 in inflammatory bowel disease. Gut 52(1):65-70. https://doi.org/10. 1136/gut.52.1.65

40. Espinoza JL, Takami A, Nakata K, Onizuka M, Kawase T, Akiyama H, Miyamura K, Morishima Y, Fukuda T, Kodera Y, Nakao S (2011) A genetic variant in the IL-17 promoter is functionally associated with acute graft-versus-host disease after unrelated bone marrow transplantation. PLoS One 6(10):e26229. https://doi.org/10.1371/journal.pone.0026229

41. Luster $\mathrm{AD}$ (2001) Chemokines regulate lymphocyte homing to the intestinal mucosa. Gastroenterology 120(1):291-294. https://doi. org/10.1053/gast.2001.21403

42. Moser B, Wolf M, Walz A, Loetscher P (2004) Chemokines: multiple levels of leukocyte migration control. Trends Immunol 25(2): 75-84. https://doi.org/10.1016/j.it.2003.12.005

43. Goodison S, Urquidi V, Tarin D (1999) CD44 cell adhesion molecules. Mol Pathol 52(4):189-196. https://doi.org/10.1136/mp.52.4. 189

44. Bonder CS, Clark SR, Norman MU, Johnson P, Kubes P (2006) Use of CD44 by CD4+ Th1 and Th2 lymphocytes to roll and adhere. Blood 107(12):4798-4806. https://doi.org/10.1182/blood2005-09-3581

45. Papadogiannakis N, Gad A, Chenard MP, Bellocq JP, Duclos B (1996) Expression of CD44 variants in differential diagnosis of ulcerative colitis and Crohn's disease. Lancet 347(9012):14131414. https://doi.org/10.1016/s0140-6736(96)91058-2

46. Sarsu SB, Yilmaz SG, Bayram A, Denk A, Kargun K, Sungur MA (2015) Polymorphisms in the IL-6 and IL-6R receptor genes as new diagnostic biomarkers of acute appendicitis: a study on two candidate genes in pediatric patients with acute appendicitis. Ital J Pediatr 41:100-105. https://doi.org/10.1186/s13052-015-0206-7

Publisher's note Springer Nature remains neutral with regard to jurisdictional claims in published maps and institutional affiliations. 